\title{
Predicting site productivity and pest hazard in lodgepole pine using biogeoclimatic system and geographic variables in British Columbia
}

\author{
Harry X. WU' ${ }^{a *}$, Cheng C. YING ${ }^{\mathrm{b}}$, Hong-Bo JU' \\ a PO Box E4008, Kingston, Canberra, ACT 2604, Australia \\ ${ }^{\mathrm{b}}$ Research Branch, BC Ministry of Forests, 712 Yates Street, Victoria, British Columbia V8W 3E7, Canada \\ ${ }^{c}$ Heilongjiang General Bureau of Forest Industry, Harbin, China
}

(Received 18 March 2003; accepted 19 April 2004)

\begin{abstract}
A series of 60 lodgepole pine provenance tests was planted throughout the interior of British Columbia in 1974 to predict productivity and pest hazard based on ecological classification and geographical variables. These 60 tests cover eight biogeoclimatic zones and 25 subzones within the biogeoclimatic ecosystem classification (BEC) in British Columbia. Ten provenances are common among 60 provenances tested at each site. Mean height (20-year) was measured at 57 of the 60 sites, incidence of western gall rust assessed at 56 sites, terminal weevil at 49 sites, and needle cast at 50 sites. There is large site-to-site variation in all traits. Geographic models using latitude, longitude and elevation of test site location as predictors explained $47 \%, 35 \%, 33 \%, 27 \%$ and $8 \%$ of site variation for height, survival, incidence of needle cast, terminal weevil and western gall rust, respectively. BEC zones accounted for about the same amount of the site variation as geographic models, suggesting both accounted for the effect of site environments relating mainly to temperature and precipitation. Within BEC zones, site variation in height seems to be related to subzones associated with moisture gradient, but not temperature. Sites in the moist, mild ICH subzone and the dry, cool MS subzone along the southern Rocky Mt. Trench represent the best forest land for intensive silviculture of lodgepole pine, being highly productive with low pest hazard except needle cast. These sites are followed in productivity by sites across the vast interior stretching from the Skeena/Bulkley river basin in the northwest (moist SBS subzone), to the interior wetbelt on Shuswap-Quesnel Highland (moist, cool ICH subzone), and the Thompson Plateau in the southern interior, where lodgepole pine grew well with relatively low pest hazard at most sites.
\end{abstract}

site productivity / pest hazard / western gall rust / needle cast / terminal weevil / ecological system

Résumé - Prévoir la productivité des stations et les risques liés aux insectes nuisibles chez Pinus contorta en utilisant un système bioclimatique et des variables géographiques en Colombie Britannique. Une série de 60 tests de provenances de Pinus contorta ont été plantés à travers l'intérieur de la Colombie britannique pour prédire la productivité et les risques liés aux insectes nuisibles sur la base d'une classification écologique et de variables géographiques. Ces 60 tests couvrent 8 zones bioclimatiques dans le système de Classification bioclimatique des écosystèmes (BEC) en Colombie Britannique. Dix provenances étaient communes parmi les 60 provenances testées dans chaque station. La hauteur moyenne (à 20 ans) a été mesurée dans 57 des 60 stations, l'incidence de la rouille de l'écorce fixée dans 56 stations, le charançon des apex terminaux dans 49 stations et la chute des aiguilles dans 50 stations. Il y a une grande variation dans tous les traits d'une station à l'autre. Un modèle géographique utilisant la latitude, la longitude et l'altitude de la station considérée comme prédicateurs explique $47 \%, 35 \%, 33 \%, 27 \%$, et $8 \%$ de la variation selon les stations respectivement pour la hauteur, la survie, l'incidence sur la chute des aiguilles, le charançon des apex terminaux et l'incidence de la rouille de l'écorce. Les zones BEC comptent pour environ la même valeur que les variations de station dans les modèles géographiques, suggérant que tous les deux comptent pour les effets de station qui se rapportent principalement à la température et aux précipitations. Dans les zones BEC, les variations de hauteurs liées à la station semblent être reliées aux sous-zones associées à des gradients d'humidité mais pas à la température. Les stations situées dans des sous-zones humides, les sous-zones douces (ICH) et les sous-zones sèches, fraîches (MS) au sud-ouest de Rocky Mt. Trench représentent le meilleur terrain pour une sylviculture intensive de Pinus contorta avec une haute productivité et des risques faibles liés aux insectes nuisibles excepté pour la chute des aiguilles. Ces sites ont été suivis pour la productivité des stations à travers le vaste intérieur en élargissant depuis le bassin de rivière Skeena/Bulkey dans le nord-ouest (sous-zone humide SBS) jusqu'à la zone intérieure humide dans les montagnes Shuswap-Quesnel (sous-zone ICH, humide et fraîche) et le plateau Thompson dans le sud-ouest intérieur où le Pinus contorta pousse bien avec des risques relativement faibles de dégâts d'insectes nuisibles dans les stations humides.

productivité des stations / risques liés aux insectes nuisibles / rouille de l'écorce / chute des aiguilles / charançon des apex / système écologique

* Corresponding author: Harry.Wu@csiro.au 


\section{INTRODUCTION}

Lodgepole pine (Pinus contorta Dougl.) is the most wideranging and one of the most variable pines in North America [4]. This species is notable for its adaptation to a wide range of environments, from low elevation, coastal bogs to alpine conditions, and occurs naturally in 12 out of the total 14 biogeoclimatic zones in British Columbia (BC) [25]. It is a major component species of natural forests in the following six biogeoclimatic zones: Montane Spruce (MS), Sub-Boreal Spruce (SBS), Engelmann Spruce-Subalpine Fir (ESSF), Boreal White and Black Spruce (BWBS), Interior Cedar-Hemlock (ICH) and Interior Douglas-Fir (IDF) in BC.

Lodgepole pine has been the primary reforestation species in $\mathrm{BC}$ since the 1960s [13]. To facilitate selection of the best provenances and the best sites for the reforestation, long-term field tests involving more than 150 provenance samples were established at about 70 locations in the Yukon and BC from 1968 to 74 [46]. In BC, test results indicated large provenance variation in geographic patterns in growth and cold hardiness $[41,42,45]$ and pest incidences $[39,44]$, and high gain through provenance selection and genetic manipulation in stem volume [43] and pest resistance [40]. The results have been used to develop seed transfer guidelines and are incorporated into tree improvement.

Efficient forest management has to be ecologically site specific. Various approaches have been attempted to establish correlations of site climatic, edaphic and biotic factors with site productivity and pest hazards in lodgepole pine and other species $[1,3,29,30]$. In British Columbia, the biogeoclimatic ecosystem classification (BEC) of forest lands represents the first step to achieve this goal of site-specific forest management. $[16,18,26]$. BC's BEC system is a hierarchical stratification of forest lands into zone, subzone and variant with increased uniformity in regional climate (vegetation-inferred); organization of forest ecosystems into BEC classifications involves the interpretative synthesis of landscape patterns, regional climates and vegetation types assuming their interactive dynamics is the causal process in the formation of forest and plant communities [26]. Within this framework of BEC classification, research has been focused on establishing a predictive relationship between site productivity and ecological site quality indicators, but mostly concentrated in the coastal region with Douglas-fir (Pseudotsuga menziesii [Mirb] Franco. var. glauca) and western hemlock (Tsuga heterophylla [Raf.] Sarg.) [5, 6, 15]. The same effort has been expanded to interior spruce (Picea engelmannii Parry and $P$. glauca (Moench) Voss) and lodgepole pine (Pinus contorta Dougl.) in site productivity [20, 34, 35] and pest hazards [19].

The obvious disadvantage of correlating site productivity or pest hazard to ecological factors using natural forests is the lack of control over stand history, e.g. stand genetic composition and other factors such as heterogeneous age, space. Evidence suggests genetic factors may be better able to track site productivity than ecological factors. Monserud and Rehfeldt [23] reported the genetic factor alone accounted for $40 \%$ of site index variation among 135 natural stands of Douglas-fir (Pseudotsuga menziesii var. glauca), one-third more efficient than environmental factors. Monserud [22] found that provenance origin (elevation in particular) explained more site index variation than the best set of environmental factors. In addition, lack of control of factors such as competition, microsite variation, and the interactions between ecological factors and stand genetic composition can further erode statistical power to reveal causality. Plantations with similar genetic background and uniform silviculture treatments like provenance and progeny tests would minimize the influence of these confounding factors. Unfortunately, provenance and progeny tests in most cases are confined to a limited site environment at only a few locations. $\mathrm{BC}$ 's core series of the lodgepole pine provenance testing established at 60 locations throughout the Interior offers a rare opportunity to study site variability in productivity and pest hazards since the experiment plots were designed with control of genetic composition, stand age, and competition. In this paper we report site variation in 20-year height and pest incidence of western gall rust (Endocronartium harknessii (J.P. More) Y. Hirat.), needle cast (Lophodermella concolor (Dern) Darker) and terminal weevil (Pissodes terminalis Hopping) attack, and construct their predictive relationships with BEC classification and site geographic location (latitude, longitude and elevation), with the main objective to delineate sites where plantation of lodgepole pine will most likely succeed - high productivity and low pest hazard.

Ecologically, lodgepole pine is a pioneer (early seral) species with low shade tolerance and rapid juvenile growth [24]. Growth at age 20 is sufficient to represent productivity at mature age. In mature stands, lodgepole pine tends to be replaced by more shade-tolerant, later seral species such as white and black spruce (Picea glauca, Picea mariana) and western hemlock (Tsuga heterophylla) unless burned by wild fires [2]. Forest fire plays an integral role in the ecology and regeneration of lodgepole pine natural stands, particularly for the subspecies latifolia in Rocky Mountains. Its serotinous cones require high intensity of heat to open and release the seeds [17].

Western gall rust and needle cast are two common diseases in many lodgepole pine plantations which can cause severe reduction in productivity and stem quality. Severe damage of lodgepole pine trees caused by western gall rust has been widely reported $[7,8,27,48]$. Widespread needle cast infection of both natural and plantation lodgepole pine in recent years has aroused the concerns of BC foresters [38]. Accumulated results in British Columbia and the United States indicate the existence of high genetic resistance to both diseases in some provenances of lodgepole pine $[9,12,44,47]$. Lodgepole pine terminal weevil usually attacks vigorous shoot terminal and causes terminal dieback of the current year's growth. The attack of terminal weevil on lodgepole pine not only causes loss of tree growth, but also reduces timber quality by inducing forked and crooked stems.

\section{MATERIALS AND METHODS}

\subsection{Test site and provenance sample}

The 60 provenance tests that represent the core of BC's lodgepole pine provenance program were planted in the same year (spring 1974) with the same stock type $(2+1$ bareroot $)$ raised at the same nursery (Red Rock Research Station, Prince George). They were organized 
Table I. Summary of location of the 60 lodgepole pine provenance test sites, and zonal average of latitude, longitude, elevation, 20-year height and pest score of western gall rust (GT), terminal weevil (WT) and needle cast (NC).

\begin{tabular}{ccccccccccc}
\hline Region & No. of site & Latitude & Longitude & Elevation $(\mathrm{m})$ & Height $(\mathrm{CM})$ & Survival $(\%)$ & GT & WT & NC \\
\hline 1 & 5 & 49.58 & 115.74 & 1390 & 689.2 & 83.3 & 0.39 & 0.07 & 2.30 \\
2 & 5 & 49.69 & 117.90 & 1468 & 678.0 & 85.5 & 1.86 & 0.22 & 2.34 \\
3 & 5 & 50.24 & 119.92 & 1406 & 622.6 & 85.1 & 0.64 & 0.54 & 1.88 \\
4 & 5 & 51.31 & 117.28 & 1170 & 657.4 & 86.4 & 1.31 & 0.21 & 2.25 \\
5 & 5 & 51.99 & 120.71 & 1154 & 671.8 & 81.9 & 0.84 & 0.30 & 2.54 \\
6 & 5 & 51.75 & 122.35 & 1176 & 506.4 & 78.9 & 0.17 & 0.41 & 2.37 \\
7 & 5 & 53.25 & 120.16 & 884 & 846.4 & 81.8 & 2.54 & 0.35 & 1.60 \\
8 & 5 & 53.26 & 122.30 & 950 & 685.0 & 82.4 & 2.74 & 0.43 & 2.14 \\
9 & 5 & 53.65 & 124.71 & 966 & 613.4 & 83.9 & 0.85 & 0.30 & 2.02 \\
10 & 5 & 55.02 & 123.70 & 818 & 711.2 & 89.6 & 4.71 & 0.58 & 1.64 \\
11 & 5 & 54.85 & 127.05 & 760 & 697.2 & 88.6 & 0.17 & 0.53 & 1.60 \\
12 & 5 & 59.09 & 125.71 & 668 & 289.3 & 58.8 & 1.94 & 0.21 & 1.84 \\
\hline
\end{tabular}

Table II. Summary of climatic and geographic description of the eight biogeoclimatic zones where the 60 tests are located ${ }^{1}$.

\begin{tabular}{|c|c|c|c|c|c|}
\hline Zone & Code & No. sites & MAT $\left({ }^{\circ} \mathrm{C}\right)$ & $\operatorname{MAP}(\mathrm{mm})$ & General features \\
\hline Interior Cedar-Hemlock & $\mathrm{ICH}$ & 14 & $2.0-8.7$ & $500-1200$ & $\begin{array}{l}\text { Low to mid-elevation windward slope east of Rocky Mts. in southeast } \\
\text { BC and Nass/Skeena river basins east of Coastal Mts. in northwest BC; } \\
\text { the most productive forest zone having the highest diversity in tree } \\
\text { species in Interior }\end{array}$ \\
\hline Mountain Spruce & MS & 8 & $0.5-4.7$ & $380-900$ & $\begin{array}{l}\text { Mid-elevation southern Interior Plateau, leeside of Coast and Cascade } \\
\text { Mts., and southern Rocky Mts. Climatically, a transitional zone } \\
\text { between IDF and ESSF; cold winter and short, warm summer }\end{array}$ \\
\hline Sub-Boreal Spruce & SBS & 20 & $1.7-5.0$ & $440-900$ & $\begin{array}{l}\text { Montane zone in central interior from valley bottom to about } 1200 \mathrm{~m} \text {; } \\
\text { cold, dry winter and cool, dry summer; climatically a broad transition } \\
\text { from the warmer-drier IDF in south, drier-warmer SBPS in southwest, } \\
\text { and colder boreal forests in north and high elevation subalpine forests }\end{array}$ \\
\hline $\begin{array}{l}2 \text { Engelmann Spruce- } \\
\text { Subalpine Fir }\end{array}$ & ESSF & 8 & $-2.0-2.0$ & $400-2200$ & $\begin{array}{l}\text { The uppermost forested lands below alpine tundra, extending to the } \\
\text { southern three quarters of Interior; cold, moist and snowy climate } \\
\text { with snow accounting for } 50-70 \% \text { of precipitation }\end{array}$ \\
\hline Interior Douglas-fir & IDF & 3 & $1.6-9.5$ & $300-750$ & $\begin{array}{l}\text { Low to mid-elevation of the valley terrain of the southern Interior Plateau } \\
\text { and southern Rocky Mt. Trench, extending to the lee side of Coastal } \\
\text { Mts.; long growing season with warm, dry summers and cool winters }\end{array}$ \\
\hline Sub-Boreal Pine-Spruce & SBPS & 2 & $0.3-2.7$ & $335-580$ & $\begin{array}{l}\text { Montane zone on the high elevation plateau in the rainshadow of } \\
\text { Coastal Mts., above IDF, below MS and SBS, with cold, dry winters } \\
\text { and cool, dry summers }\end{array}$ \\
\hline $\begin{array}{l}2 \text { Boreal White and } \\
\text { Black Spruce }\end{array}$ & BWBS & 4 & $-2.9-2.0$ & $330-570$ & $\begin{array}{l}\text { An extension of the Great Plains (Alberta Plateau) into the lower ele- } \\
\text { vation of the main valley west of Rocky Mts. in northern BC; short } \\
\text { growing season with long, very cold winters }\end{array}$ \\
\hline Spruce-Willow-Birch & SWB & 1 & $-0.7-3.0$ & $460-700$ & $\begin{array}{l}\text { The most northerly subalpine zone in BC above BWBS; long. cold } \\
\text { winter and cool and brief summer }\end{array}$ \\
\hline
\end{tabular}

${ }^{1}$ Information based on Meidinger D. and Pojar J. (Eds.) 1991. Ecosystems of British Columbia. BC Ministry of Forests, Special Report Series 6, 330 p. 2 No data from one high elevation site in ESSF because of access difficulty and two sites in BWBS lost to road construction and other accidents.

$\mathrm{MAT}=$ mean annual temperature; $\mathrm{MAP}=$ mean annual precipitation .

into 12 geographic regions delineated according to latitude and precipitation $[14,45]$. Within each region, five sites were selected so that major local site variables, such as soil and elevation, could be sampled (Fig. 1 and Tab. I). The 60 sites span approximately $11^{\circ}$ of latitude ( $49^{\circ} 05^{\prime}$ to $\left.59^{\circ} 47^{\prime}\right), 15^{\circ}$ of longitude $\left(114^{\circ} 41^{\prime}\right.$ to $\left.129^{\circ} 08^{\prime}\right)$ and $1450 \mathrm{~m}$ of elevation ( 380 to $1830 \mathrm{~m}$ ), and cover eight biogeoclimatic zones
(Tab. II) where lodgepole pine is the major component species in natural forests except the Spruce-Willow-Birch zone [25]. Fifty of the 60 sites are located in four BEC zones, ICH, SBS, MS and ESSF (Tab. II). These four BEC zones are referred to as major zones in this paper, and their climatic and geographic features are described in Table II [21]. All the test sites are typical lodgepole pine sites with the exception of 


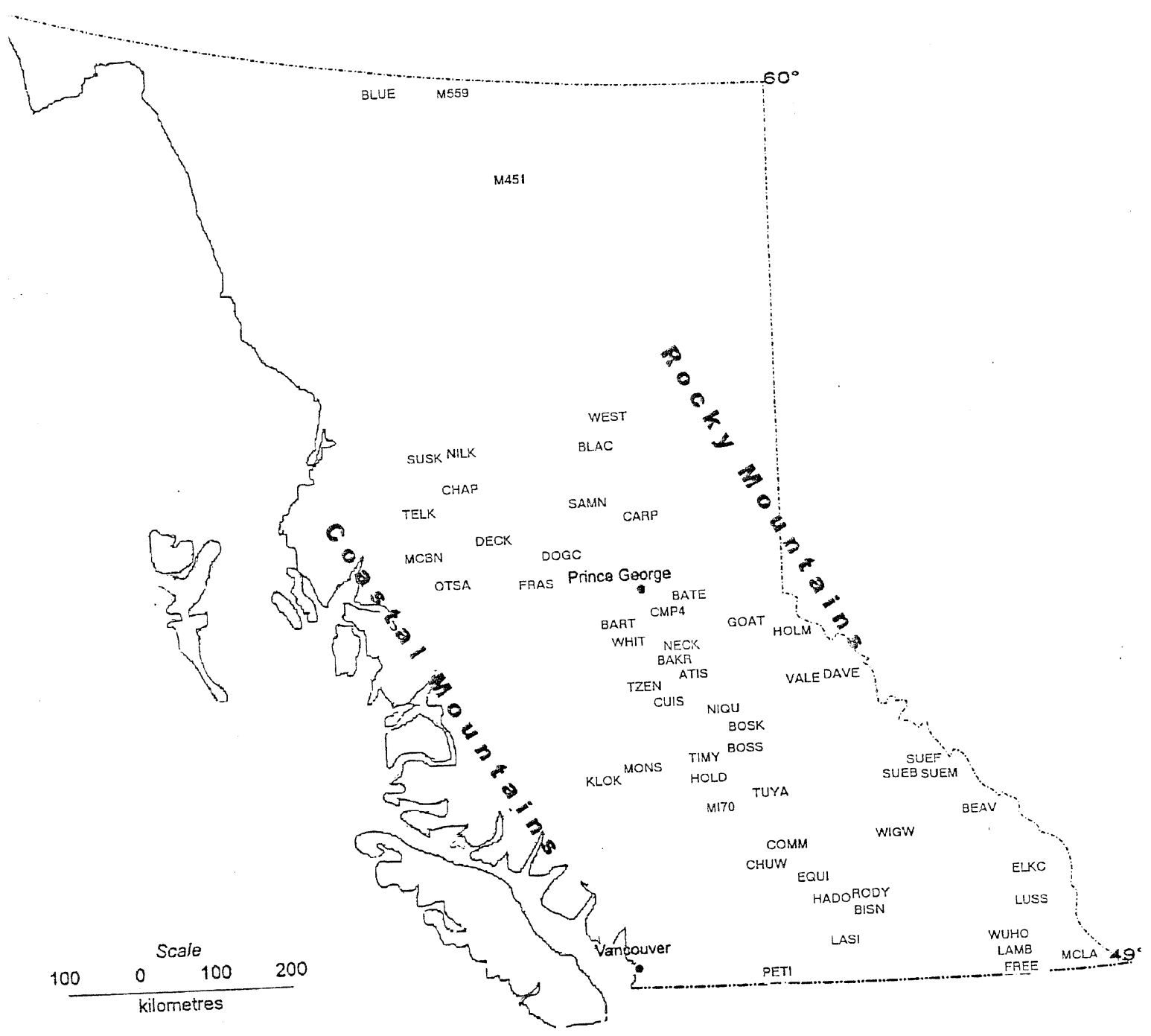

Figure 1. Locations of the 60 lodgepole pine provenance tests.

the highest elevation site at Terraced Peak $(1830 \mathrm{~m})$ where Engelmann spruce (Picea engelmannii) and subalpine fir (Abies lasiocarpa) dominate the forest landscape and Goat River in ICH where western redcedar (Thuja plicata), western hemlock (Tsuga heterophylla) and white spruce (Picea glauca) are the major components in original stands. Two sites in region 12 (Mile 250 and Kledo Cr.) (Fig. 1) were abandoned because of damage caused by road construction and high early mortality, and one high elevation site in region 2 (Terraced Pk.) was not assessed because of difficulty of access. At each site, a subset of 60 provenances from a total of 142 populations collected rangewide were planted in two blocks in a completely randomized block design with individual provenances planted in a 3 by 3 tree square plot with $2.5 \mathrm{~m}$ spacing. The 60 provenances comprised, all populations indigenous to the region, most populations from adjacent regions, and a few from the extremes of the species' range. There were 30-40 provenances overlapping between adjacent regions and 10 standard provenances representing the species entire range were tested at all the 60 tests. Provenance variation and provenance by site interaction using the 10 standard provenances were examined in a previous study [41].

\subsection{Data collection}

Height of individual trees was measured at all 57 sites in the fall of 1994, 20 years after planting using a laser gun. Incidence of western gall rust, needle cast and terminal weevil attack were assessed during the summer months of 1993 (24 sites), 94 (30 sites) and 95 (3 sites). These three pests were the common ones at the provenance test sites and can cause severe damage to plantation lodgepole pine. Western gall rust was assessed at 56 sites, needle cast at 50 sites and terminal weevil at 49 sites (Tab. I).

Total number of galls on both branches and main stem were counted for each tree; the woody, globose perennial galls caused by the rust are simple to recognize. The terminal weevil attacks and kills the leader terminals. Fading leaders indicate current weevil activity; and dead stubs on the stem where forking or crooking occurred are evidence of previous years' attacks [32]; so the presence of dead stub or dying leader is recognized as attack and their total number along the stem were counted. This probably underestimates the actual number of attacks because snow, wind, branch rubbing, strong recovery of the lateral, etc. can eliminate the stubs. Both the assessment of the stem rust and weevil incidence were an estimate of cumulative attack. Needle cast infection for individual trees was rated according to percentage needle infection: $1=$ less than $5 \%$ needles infected; $2=5$ to $25 \%$ needles infected; $3=25$ to $50 \%$ needles infected; $4=50-75 \%$ needles infected; $5=$ over $75 \%$ needles infected. It was based on the current year infection; assessment of cumulative needle cast infection is not 


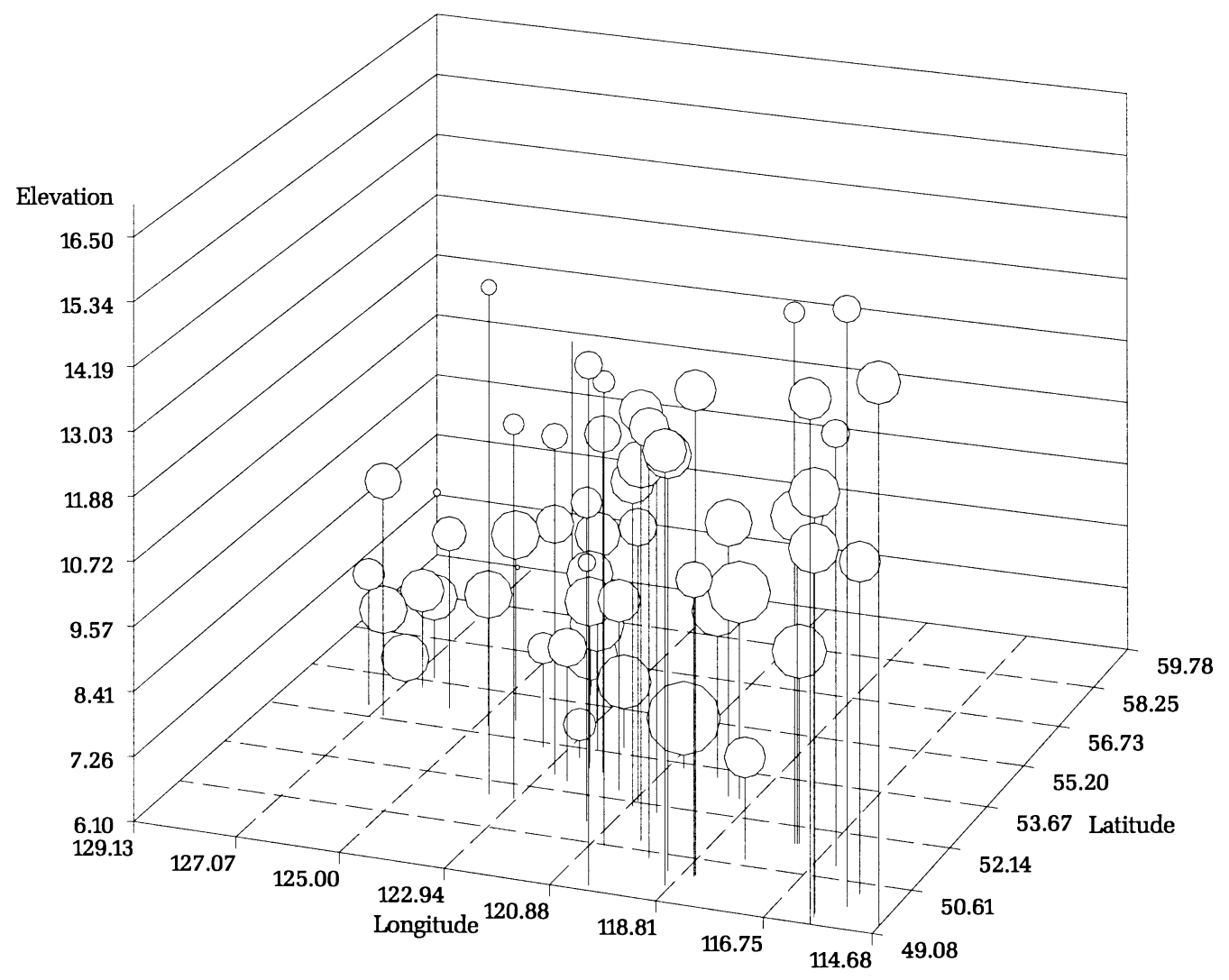

Figure 2. Effect of latitude, longitude, and elevation on tree height of lodgepole pine.

practical because it is difficult, if not impossible, to distinguish from other factors which may cause needle barren, e.g. male cone reproduction, frost, etc. Needle samples were sent for laboratory examination and Lophodermella concolor (Dern) Darker was identified as the causing pathogen.

\subsection{Data analysis}

Site means of 20-year height and pest incidence were based on all provenances as indicators of relative site productivity and pest hazards. Nested analysis of variance was used to test the site effect associated with BEC zones and subzones; subzone effects associated with moisture and temperature gradients were further examined separately. Pearson linear correlation was used to examine among-trait relationships [31]. In an attempt to establish predictive relationship of site productivity, survival rate and pest incidences with geographic variables and BEC site classifications gradient, data were subjected to the following regression analyses:

(1) Stepwise regression screening of latitude, longitude, elevation, and their squares and products as predictors. Site variation is considered continuous. The model was selected according to the criteria that both the model and predictor variables were significant at 0.05 probability level and Mallow's statistic $\left(\mathrm{C}_{\mathrm{p}}\right)$ was closest to the number of predictor variables included in the model [36].

(2) Multiple regression by fitting BEC zones as qualitative variables ( 0 or 1$)$ representing the 8 zones with test sites (Tab. II). Site variation between zones is considered discrete.

(3) Multiple regression by fitting both BEC zones and subzones associated with moisture gradient within each BEC zone (Tab. II) as qualitative variables 0 or 1 . Site variation is considered discrete at two levels with subzones nested within zones. Only subzones associated with moisture were examined as initial ANOVA indicated no significant association of temperature gradients with any of the traits. Both temperature and precipitation are the determinant factors in BEC classification, temperature probably being the dominant one at zone level delineation whereas moisture gradient which subjects to the modification effect of local landform influences subzone classification [26].

Models 2 and 3 quantify the average site effect associated with individual BEC zones and subzones which would allow the assessment of the degree of discrete changes along BEC land classifications. Stand error of model estimate was used as the criterion to judge the degree of discontinuity. The purpose of the above regression analyses is (1) to examine predictability of geographic coordinates (as surrogate environmental variables) and BEC classification to account for site variability and (2) where, along the BEC classifications, discrete variation may exist. One caution is that estimates of zone or subzone effect can be spurious since sites are not equally distributed or represented in all BEC units. However, as site choice was consciously made to sample the temperature and precipitation gradients [14], estimate of zone effect (at least the major zones) ought to be sound. All calculations were furnished by SAS software package [28].

\section{RESULTS}

\subsection{Height and survival}

Trees at the most productive site grew four times larger than at the least productive one in 20 years $(10.1 \mathrm{~m}$ at Goat River vs. $2.5 \mathrm{~m}$ at M451) (Tab. I and Fig. 2). As expected, sites in the 
Table III. Effect of biogeoclimatic zone and subzone on site variation in height, survival and pest scores of western gall rust (GT), terminal weevil (WT) and needle cast (NC).

\begin{tabular}{lcccccccccc}
\hline & \multicolumn{2}{c}{ Height } & \multicolumn{2}{c}{ Survival } & & GT & & WT & \multicolumn{2}{c}{ NC } \\
\hline Sources of variation & $\mathrm{df}$ & $p$. & $\mathrm{df}$ & $p$. & $\mathrm{df}$ & $p$. & $\mathrm{df}$ & $p$. & $\mathrm{df}$ & $p$. \\
Zone & 7 & 0.001 & 7 & 0.001 & 7 & 0.813 & 7 & 0.028 & 7 & 0.003 \\
Subzone (zone) & 16 & 0.015 & 16 & 0.293 & 16 & 0.743 & 15 & 0.205 & 15 & 0.043 \\
Residual & 33 & & 33 & & 32 & & 26 & & 27 \\
Total & 56 & & 56 & & 55 & & 48 & & 49 \\
\hline
\end{tabular}

Table IV. Effect of biogeoclimatic zone and subzone associated with moisture gradients on site variation in height, survival and pest scores of western gall rust (GT), terminal weevil (WT) and needle cast (NC).

\begin{tabular}{lcccccccccc}
\hline & \multicolumn{2}{c}{ Height } & \multicolumn{2}{c}{ Survival } & \multicolumn{2}{c}{ GT } & & WT & \multicolumn{2}{c}{ NC } \\
\hline Sources of variation & $\mathrm{df}$ & $p$. & $\mathrm{df}$ & $p$. & $\mathrm{df}$ & $p$. & $\mathrm{df}$ & $p$. & $\mathrm{df}$ & $p$. \\
Zone & 7 & 0.001 & 7 & 0.001 & 7 & 0.597 & 7 & 0.046 & 7 & 0.014 \\
Moisture (zone) & 7 & 0.003 & 7 & 0.385 & 7 & 0.858 & 7 & 0.041 & 7 & 0.123 \\
Residual & 42 & & 42 & & 41 & & 34 & & 35 \\
\hline
\end{tabular}

Table V. Effect of biogeoclimatic zone and subzone associated with temperature gradients on site variation in height, survival and pest scores of western gall rust (GT), terminal weevil (WT) and needle cast (NC).

\begin{tabular}{lcccccccccc}
\hline & \multicolumn{2}{c}{ Height } & \multicolumn{2}{c}{ Survival } & & GT & & WT & NC \\
\hline Sources of variation & df & $p$. & df & $p$. & df & $p$. & df & $p$. & df & $p$. \\
Zone & 7 & 0.001 & 7 & 0.001 & 7 & 0.778 & 7 & 0.057 & 7 & 0.003 \\
Temperature (zone) & 9 & 0.278 & 9 & 0.118 & 9 & 0.341 & 9 & 0.689 & 9 & 0.238 \\
Residual & 40 & & 40 & & 39 & & 32 & & 33 \\
\hline
\end{tabular}

Table VI. Geographic models derived from stepwise regression of site variation in height, survival, and pest score of western gall rust (GT), terminal weevil (WT), needle cast (NC).

\begin{tabular}{|c|c|c|}
\hline Traits & $R^{2}$ & Regression equation $^{\mathrm{a}}$ \\
\hline Height & 0.470 & $2751.16456-2.0622 \times$ elevation $^{2}-0.28827 \times$ latitude $\times$ longitude \\
\hline Survival & 0.348 & $-1832.1558+71.0712 \times$ latitude $-0.6608 \times$ latitude $^{2}+0.0712 \times$ elevation $^{2}$ \\
\hline GT & 0.076 & $4.5235-0.0023 \times$ longitude $\times$ elevation \\
\hline WT & 0.269 & $-6.0926+0.0751 \times$ longitude $-0.00042 \times$ latitude $\times$ longitude \\
\hline $\mathrm{NC}$ & 0.334 & $2.8066+0.7124 \times$ elevation $-0.03466 \times$ elevation $^{2}-0.00065 \times$ latitude $\times$ longitude \\
\hline
\end{tabular}

a All equations significant at 0.05 probability level; elevation in unit $100 \mathrm{~m}$.

ICH zone were the most productive ones (average $7.5 \mathrm{~m}$ ); 5 of the 10 most productive sites were in ICH. The least productive sites were in SBW and BWBS zones in northern BC (Tab. I). On average, sites in SBS were the second most productive ones $(6.8 \mathrm{~m})$, followed by sites in MS zone $(6.4 \mathrm{~m}), \mathrm{ESSF}(6.3 \mathrm{~m})$, IDF $(5.8 \mathrm{~m})$ and SBPS $(4.4 \mathrm{~m})$. Thus, relative site productivity of BEC zones as measured by these test sites seems to correlate well with zonal climate (Tab. II). Differences in site mean height among BEC zones were statistically significant (Tab. III). Differences among BEC subzones within zones were also significant, but associated only with moisture gradient (Tab. IV), not temperature gradient (Tab. V).
Mean site heights (Tab. I) are plotted in Figure 2; the geographic model accounted for $47 \%$ of its variation (Tab. VI) which depicted a southeast-northwest trend with a curvilinear elevation cline - site productivity declines as elevation or latitude/ longitude of site increases. BEC zones explained $56 \%$ of site variation (Model 2, Tab. VII). Steep differentiation (degree of discrete variation) occurred along the SWB-BWBS boundary (SWB occupies the subalpine zone above BWBS, Tab. II), using the standard error of the model estimate as the criterion (Tab. VII). Differentiation along the SBPS zone boundary (dry high elevation plateau) was also steep. Otherwise, between-zone differentiation among other BEC zones was essentially continuous. 
Table VII. Regression models by fitting site variation in height, survival, and pest score of western gall rust, terminal weevil and needle cast to biogeoclimatic zones and subzones.

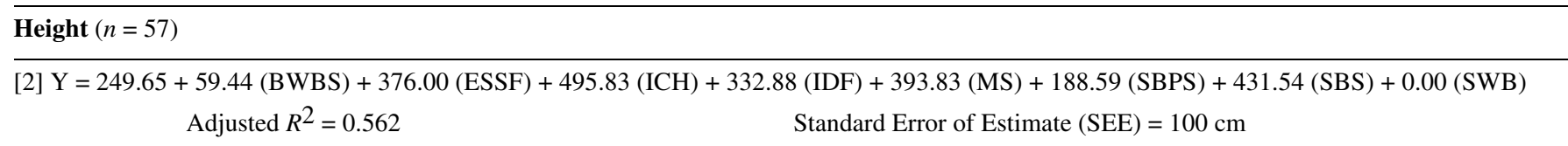

$[3] \mathrm{Y}=249.65+59.44(\mathrm{BWBS})+368.81(\mathrm{ESSF})+762.34(\mathrm{ICH})+494.25(\mathrm{IDF})+259.40(\mathrm{MS})+188.59(\mathrm{SBPS})+470.72(\mathrm{SBS})+0.00(\mathrm{SWB})+$ $0.00(\mathrm{BWBSd})+14.05(\mathrm{ESSFd})+8.19(\mathrm{ESSFm})+0.00(\mathrm{ESSFw})-287.01(\mathrm{ICHm})+0.00(\mathrm{ICHw})-242.05(\mathrm{IDFd})+0.00(\mathrm{IDFm})+179.24(\mathrm{MSd})+$ $0.00(\mathrm{MSx})+0.00(\mathrm{SBPSx})-105.99(\mathrm{SBSd})-19.52(\mathrm{SBSm})+0.00(\mathrm{SBSw})+0.00(\mathrm{SWBm})$

$$
\text { Adjusted } R^{2}=0.718 \quad \text { Standard Error of Estimate }(\mathrm{SEE})=86 \mathrm{~cm}
$$

Survival $(n=57)$

[2] $\mathrm{Y}=80.64-32.78(\mathrm{BWBS})+6.56(\mathrm{ESSF})+2.21(\mathrm{ICH})-0.03(\mathrm{IDF})+2.61(\mathrm{MS})-2.17(\mathrm{SBPS})+5.13(\mathrm{SBS})+0.00(\mathrm{SWB})$

Adjusted $R^{2}=0.463 \quad$ Standard Error of Estimate (SEE) $=7.7 \%$

$[3] \mathrm{Y}=80.64-32.78(\mathrm{BWBS})+3.18(\mathrm{ESSF})+5.28(\mathrm{ICH})+6.67(\mathrm{IDF})+3.22(\mathrm{MS})-2.17(\mathrm{SBPS})+4.64(\mathrm{SBS})+0.00(\mathrm{SWB})+0.00(\mathrm{BWBSd})+$ $5.10(\mathrm{ESSFd})+8.30(\mathrm{ESSFm})+0.00(\mathrm{ESSFw})-3.30(\mathrm{ICHm})+0.00(\mathrm{ICHw})-10.04(\mathrm{IDFd})+0.00(\mathrm{IDFm})-0.82(\mathrm{MSd})+0.00(\mathrm{MSx})+$ $0.00(\mathrm{SBPSx})-6.60(\mathrm{SBSd})+3.30(\mathrm{SBSm})+0.00(\mathrm{SBSw})+0.00(\mathrm{SWBm})$
Adjusted $R^{2}=0.546$
Standard Error of Estimate $(\mathrm{SEE})=7.6 \%$

Western gall rust $(n=56)$

$[2]^{\mathrm{a}} \mathrm{Y}=3.57-3.27(\mathrm{BWBS})-3.25(\mathrm{ESSF})-1.81(\mathrm{ICH})-2.79(\mathrm{IDF})-3.05(\mathrm{MS})-3.55(\mathrm{SBPS})-1.29(\mathrm{SBS})+0.00(\mathrm{SWB})$

Adjusted $R^{2}=0.111 \quad$ Standard Error of Estimate $(\mathrm{SEE})=2.65$

$[3]^{\mathrm{a}} \mathrm{Y}=3.57-3.27(\mathrm{BWBS})-2.94(\mathrm{ESSF})-3.41(\mathrm{ICH})-1.56(\mathrm{IDF})-3.34(\mathrm{MS})-3.56(\mathrm{SBPS})+1.05(\mathrm{SBS})+0.00(\mathrm{SWB})+0.00(\mathrm{BWBSd})-$ $0.54(\mathrm{ESSFd})-0.53(\mathrm{ESSFm})+0.00(\mathrm{ESSFw})+1.72(\mathrm{ICHm})+0.00(\mathrm{ICHw})-1.85(\mathrm{IDFd})+0.00(\mathrm{IDFm})+0.39(\mathrm{MSd})+0.00(\mathrm{MSx})+$ $0.00(\mathrm{SBPSx})-3.58(\mathrm{SBSd})-2.23(\mathrm{SBSm})+0.00(\mathrm{SBSw})+0.00(\mathrm{SWBm})$

$$
\text { Adjusted } R^{2}=0.077 \quad \text { Standard Error of Estimate (SEE) }=2.76
$$

Terminal Weevil $(n=49)$

[2] $\mathrm{Y}=0.10+0.21(\mathrm{BWBS})+0.10(\mathrm{ESSF})+0.12(\mathrm{ICH})+0.25(\mathrm{IDF})+0.34(\mathrm{MS})+0.37(\mathrm{SBPS})+0.37(\mathrm{SBS})+0.00(\mathrm{SWB})$

$$
\text { Adjusted } R^{2}=0.289 \quad \text { Standard Error of Estimate (SEE) }=0.21
$$

$[3] \mathrm{Y}=0.10+0.21(\mathrm{BWBS})+0.06(\mathrm{ESSF})+0.06(\mathrm{ICH})+0.23(\mathrm{IDF})+0.69(\mathrm{MS})+0.37(\mathrm{SBPS})+0.56(\mathrm{SBS})+0.00(\mathrm{SWB})+0.00(\mathrm{BWBSd})+$ $0.01(\mathrm{ESSFd})+0.25(\mathrm{ESSFm})+0.00(\mathrm{ESSFw})+0.07(\mathrm{ICHm})+0.00(\mathrm{ICHw})+0.02(\mathrm{IDFd})+0.00(\mathrm{IDFm})-0.46(\mathrm{MSd})+0.00(\mathrm{MSx})+0.00$ $($ SBPSx $)-0.42(\mathrm{SBSd})-0.14(\mathrm{SBSm})+0.00(\mathrm{SBSw})+0.00(\mathrm{SWBm})$

Adjusted $R^{2}=0.457$

Standard Error of Estimate $(\mathrm{SEE})=0.19$

Needle Cast $(n=50)$

[2] $\mathrm{Y}=1.80+0.08(\mathrm{BWBS})-0.05(\mathrm{ESSF})+0.32(\mathrm{ICH})+1.37(\mathrm{IDF})+0.59(\mathrm{MS})+0.09(\mathrm{SBPS})+0.02(\mathrm{SBS})+0.00(\mathrm{SWB})$

Adjusted $R^{2}=0.377 \quad$ Standard Error of Estimate $(\mathrm{SEE})=0.49$

[3] $\mathrm{Y}=1.80+0.08(\mathrm{BWBS})+0.06(\mathrm{ESSF})-0.04(\mathrm{ICH})+1.79(\mathrm{IDF})-0.14(\mathrm{MS})+0.09(\mathrm{SBPS})-0.15(\mathrm{SBS})+0.00(\mathrm{SWB})+0.00(\mathrm{BWBSd})-$ $0.38(\mathrm{ESSFd})+0.33(\mathrm{ESSFm})+0.00(\mathrm{ESSFw})+0.39(\mathrm{ICHm})+0.00(\mathrm{ICHw})-0.64(\mathrm{IDFd})+0.00(\mathrm{IDFm})+0.98(\mathrm{MSd})+0.00(\mathrm{MSx})+$ $0.00($ SBPSx $)+0.44(\mathrm{SBSd})+0.07(\mathrm{SBSm})+0.00(\mathrm{SBSw})+0.00(\mathrm{SWBm})$

Adjusted $R^{2}=0.477$

Standard Error of Estimate $(\mathrm{SEE})=0.47$

a Model not significant at $=0.05$.

A positive correlation between moisture gradient and height was found in four of the five BEC zones where more than two subzones associated with a moisture gradient had test sites. In the SBS zone, when moisture level increased from dry to moist to wet, average height increased from 6.1 to 7.0 to $7.2 \mathrm{~m}$; in MS, mean height from very dry to dry subzones increased from 5.1 to $6.9 \mathrm{~m}$; in IDF, when moisture gradient increased from dry to moist, mean height increased from 5.0 to $7.4 \mathrm{~m}$; similarly in ICH, mean height in the wet subzone was $10.1 \mathrm{~m}$ compared to $7.2 \mathrm{~m}$ in the moist subzone. These differences were statistically significant (Tab. VII). Only in ESSF zone, height was not significantly associated with moisture gradients of subzones from dry, moist to wet (6.3, 6.2 and $6.2 \mathrm{~m}$ respectively).

Survival varied from $47.0 \%$ at Blue River to $96.6 \%$ at Telkwa with average survival of $82.9 \%$ for the 57 sites (Tab. I), and differences among BEC zones are statistically significant (Tab. III). However, excluding the two sites, Blue R. and M599, in BWBS in northern BC, site variation in survival was not large (66 to 97\%). 


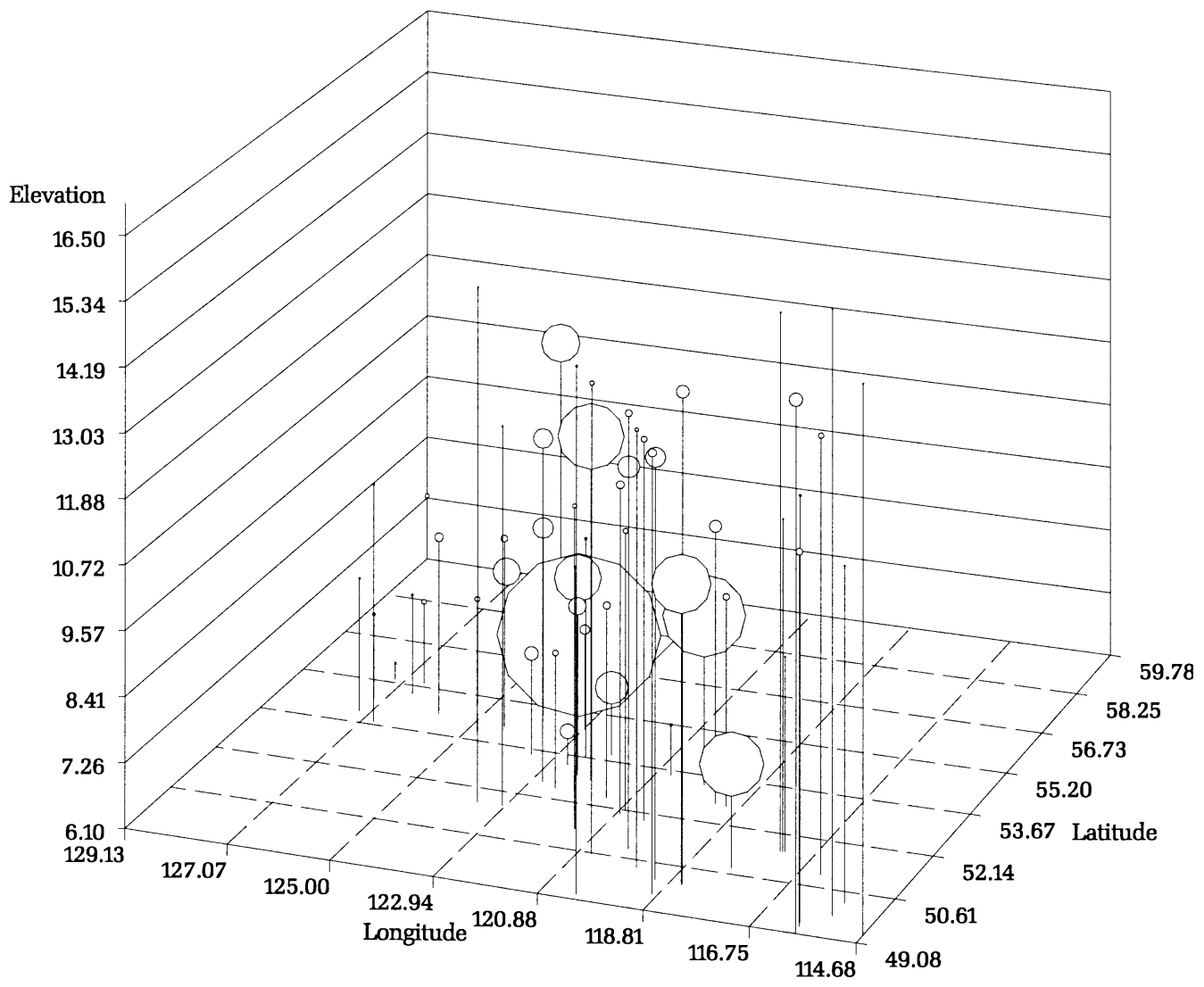

Figure 3. Effect of latitude, longitude, and elevation on western gall rust infection on lodgepole pine.

The geographic model accounted for $35 \%$ of site variation (Tab. VI). But BEC models (Tab. VII) indicate the two northern sites in BWBS with high mortality were the major contributing source to the statistical significance; excluding BWBS, none of the between-zone or subzone differences was larger than the standard errors (Tab. VII). Indeed, no statistical significance was detected in ANOVA or regression models, excluding these two northern sites.

\subsection{Western gall rust}

A large variation of gall rust infection was observed among sites, the most heavily infected site had over 150 times more galls per tree than the least infected ones (Tab. I, Fig. 3). But the variation was not associated with BEC forest classifications (Tabs. III-V and VII) and showed only a very weak geographic trend (Tab. VI). However, site variation, as shown in Figure 3, does not seem to be random; apparently, highly infected sites were concentrated in three geographic areas: Williston L. basin in the moist, cool SBS subzone, east of upper Quesnel R. in the wet, cool SBS subzone, and in West Kootenay in the moist, warm ICH subzone in the southern interior; and the least infected sites along the western edge of the Interior (east of the Coastal Mts.) and along the southern Rocky Mt. Trench (Fig. 3). A positive relationship between gall rust and moisture gradients of subzones was found in SBS (average number of galls per tree rose from 1.05 to 2.40 to 4.63 from dry, moist to wet subzone), MS (from 0.24 in very dry subzone to 0.62 in dry subzone), IDF (from 0.16 in dry subzone to 2.02 in the wet subzone), and ESSF (from 0.09 in dry subzone to 0.11 in moist subzone and to 0.64 in wet subzone). It appears that high moisture site favors the infection of western gall rust.

On average, sites in SBS and ICH had the highest number of galls per tree, 2.28 and 1.76, respectively; the seven most heavily infected sites are in these two zones (Tab. I). Sites in ESSF and SBPS were the least infected, averaging 0.02 and 0.33 galls per tree respectively and those in MS and IDF zones intermediate, 0.53 and 0.78 galls per tree, respectively. Mile 451 in the SWB had relatively high gall incidence (3.57 galls per tree) and the Blue River site in BWBS zone had few galls ( 0.30 galls per tree), but there is only one site in each of these two zones.

\subsection{Terminal weevil}

Terminal weevil attacks varied from 0.03 attacks per tree at Wuho Cr. to 0.86 attacks per tree at Salmon L. with an average of 0.34 attacks per tree for the 49 sites. The least attacked sites were concentrated along the Southern Rocky Mt. Trench in southeastern BC. Differences among BEC zones were statistically significant (Tab. III), and also subzones associated with moisture gradient (Tab. IV) but not with temperature gradient 
Table VIII. Correlations of site means in height, survival and pest scores of western gall rust (GT), terminal weevil (WT) and needle cast (NC).

\begin{tabular}{|c|c|c|c|c|c|}
\hline \multicolumn{6}{|c|}{ Traits } \\
\hline & Height & Survival & GT & WT & $\mathrm{NC}$ \\
\hline Height & 1.000 & $0.458 * *$ & -0.020 & -0.167 & 0.040 \\
\hline Survival & & 1.000 & -0.075 & 0.139 & -0.240 \\
\hline GT & & & 1.000 & -0.047 & 0.065 \\
\hline WT & & & & 1.000 & -0.182 \\
\hline $\mathrm{NC}$ & & & & & 1.000 \\
\hline
\end{tabular}

** significant at 0.01 probability level; not significant otherwise.

(Tab. V). The seven most heavily attacked sites were in MS (0.78-0.80) and SBS zone (0.63-0.86) (Tab. I). On average, the SBS, SBPS and MS zones had the most weevil attacks $(0.44$ 0.47); the IDF, BWBS, ICH and ESSF zones had relatively low weevil attacks (0.20-0.35). The SWB zone had the least weevil attacks ( 0.10 attacks per tree). Relationship between terminal weevil and moisture gradient was not consistent though statistically significant (Tab. IV); weevil attack was positively related to moisture gradient in MS (from 0.24 to 0.52 to 0.66 from dry to moist to wet subzones, respectively), but negative in SBS (from 0.79 to 0.32 from very dry to dry subzones).

The geographic model accounted for $27 \%$ of the site variation which showed a northwest to southeast trend (Tab. VI). BEC zones explained about the same amount of variation $(29 \%)$. No clear discrete changes could be detected (Model 2, Tab. VII).

\subsection{Needle cast}

Mean score of needle cast incidence was 2.07 ranging from 1.31 (Dog Cr.) to 3.59 (Thuya L.) in a scale of 1 to 5 (Tab. I). Generally, sites in central and southeastern Interior had higher needle cast incidence than those in the north and northwest. The 10 most infected sites (score $>2.9$ ) were scattered in three BEC zones: 3 each in ICH and IDF, and 4 in MS. On average, IDF zone had the highest needle cast incidence (3.12), MS was the second (2.39), and ICH the third (2.12). The other five zones had similar levels of needle cast infection (1.75 for ESSF to 1.89 for SBPS).

Analysis of variance suggests both BEC zone and subzone effects on site needle cast incidence were statistically significant (Tab. III); but neither the effect of moisture or temperature gradient was significant when analyzed separately (Tabs. IV and V). Regression analyses seem to indicate a sharp increase in needle cast in IDF (dry, low-elevation valley sites, Tab. II) (Model 2, Tab. VII). Among the four major zones, ESSF and SBS had substantially lower needle cast incidence than ICH and MS, though not statistically significant (Model 2, Tab. VII). BEC zones accounted for $38 \%$ of the variation (Tab. VII). At subzone level, needle cast incidence was positively related to moisture gradient within IDF and MS zones. In IDF needle cast score increased from 2.95 to 3.59 from dry to moist subzones; in the MS zone, from 1.66 to 2.63 from very dry to dry subzone; the relationship in ESSF and SBS was unclear (Model 3, Tab. VII).
The geographic model (accounting for $33 \%$ of the site variation in needle cast) depicts a geographic cline with increasing incidence from northwest to southeast, and a curvilinear relationship with elevation, increasing incidence with increasing site elevation which peaks at about $1000 \mathrm{~m}$ and then decreases (Tab. VI).

\subsection{Between-trait correlations}

Sites with higher productivity had higher survival rate $(r=$ 0.46 and significant, Tab. VIII). This is because productive sites have more favorable environment for survival. No significant correlation was detected between height and any of the pest traits or among the pest traits.

\section{DISCUSSION}

Both BEC zones and geographic models explained about the same amount $(50 \%)$ of the site variation in height (Tabs. VI and VII) suggesting either can predict equally well site productivity across BC interior; both reflect essentially coarse-grained site environments prescribed by temperature and precipitation gradients [26]). However, the former can only project zonal average, while the latter can estimate the productivity of any site location given geographic coordinates. The geographic model projects a loss of $0.3 \mathrm{~m}$ in 20 -year height per $100 \mathrm{~m}$ elevation increase of planting site below $1000 \mathrm{~m}$, above that the loss would be $0.5 \mathrm{~m}$; and $0.3 \mathrm{~m}$ loss per one degree increase of latitude and longitude. The models, however, left unexplained about half of the site productivity variation. Models which are able to predict lodgepole pine site productivity with high precision need to include edaphic factors as shown by Wang et al. [35]. Positive correlations between height and site moisture gradient (Model 3, Tab. VII) also suggest the effect on productivity of site-specific edaphic factors.

Despite the large site differences in all three pest traits (Tab. I) and the apparent regional trends (Fig. 3 and Tab. I), neither geographic nor BEC models provided a high level of predictability (Tabs. VI and VII). However, positive association of high pest incidence with site moisture gradients of subzones seems to indicate high site moisture may be conducive to all three pests, to some degree (Model 3, Tab. VII). Severe western gall rust tends to occur regionally in interior BC [37, 38] suggesting the influence of factors specific to local site environment. Western gall rust is the most common and destructive 
stem rust of lodgepole pine, and considerable effort has been spent to control it [33].

Very little is known about the ecology and impact of Pissodes terminalis despite its degrading effect on stem quality of lodgepole pine [32]. McLauchlan and Borden's study [19] represents the first comprehensive attempt in $\mathrm{BC}$ to quantify its impact and to relate its attack to site environment. Their study is not directly comparable to ours, e.g. natural stand vs plantation, local host source vs mixture of seed sources, different density and spacing, etc. However, attack intensity in terms of average number of attacks per tree was comparable at sites in MS zone in the same region $(0.59 \mathrm{vs} .0 .52)$, but intensity was much lower in IDF zone in our study ( 0.35 vs. 0.67$)$; the IDF test sites in our study are located in wetter and cooler subzones than McLauchlan and Borden's study plots [19]. Much remains to be learned about this potentially damaging insect.

Needle cast infection at these same sites reported by Ying and Hunt [47] showed stronger elevation and longitudinal trends than were found in this study. The major discrepancy was the severe needle cast at the dry sites in IDF zone (Tab. I) where infection was very light in 1983 and 1984 [47]. An insect and disease survey $[37,38]$ also reported heavy Lophodermella concolor at dry sites in IDF only in recent years. Needle cast infection fluctuates greatly from region to region depending on the weather of the year. Wet summer and fall favors the spread of the disease [11, 37, 38]. Both Ying and Hunt [47] and this study found frequent severe needle cast at moist valley bottom sites.

A major finding of this study was that it was more difficult to predict infection of pests using either BEC or geographic variables than predicting growth. There may be several causes for the low correlation between pests and BEC system in this experiment.

(1) Number of sampling site may be too small within each of the eight BEC zones and 25 subzones. Only 60 sites were sampled within the 25 large subzones. Most subzones only sampled a single or two sites. To adequately sample each zone and subzone and variant within each subzone, more sites may be needed for a more detailed examination.

(2) There are large variations within each BEC and subzones associated with micro-site factors such as variation on soil, slope, vegetation composition. There are also variations on history of stand, stand management due to recent fire, harvesting of nearby plots, and cattle grazing. These micro-site variations were not characterized in this study.

(3) The BEC system may be too general and simple at current stage to account for local variation responsible for pest infestation. BEC system mainly accounted for factors of mean annual temperature, precipitation, and vegetation. Other factors relevant to dynamics of pest infection such as within-year variation on moisture and temperature, under-canopy vegetation, distance to infected sites outside the studied regions and plots, surrounding vegetation and previous silviculture regime may influence the level of infestation of these pests. For example, we inspected the infection level in naturally regenerated stands near the test sites having severe gall rust in Blackwater Creek (BLAC) and Weston Creek (WEST); without exception, infection levels were also high in these surrounding natural stands. This further suggests the effect of local factors including perhaps the stand history of infection [10].
Lack of between-site correlations of height with pest severity, and among pests (Tab. VIII) suggests that site factors which determine site productivity may be different from that affecting pest incidence and that there is little association of common site environments in host-pest systems among the three pests. Despite this lack of correlation at broad geographic scale, at individual sites pest effect on height and survival was quite obvious. For example, severe western gall rust (5.58 galls per tree) and needle cast (average score 3.32) at Bisson L. were the main cause of high mortality (29\%), and the same was apparent at Wigwam (mortality 26\%) with an average of 6.07 galls per tree and repeated needle cast. Heavy gall rust at Blackwater (15.52 galls per tree), and weevil attack at Salmon L. (63\% trees attacked) and McBride L. (68\% attacked) significantly reduced the height growth at these sites.

There is very limited publication on the major causes of the variation on infestation of the three pests studied here. Most information was from regular surveys of the pests conducted in natural populations [38]. Heavy infection for western gall rust and needle cast was particularly associated with moist environment [47]. In conclusion from previous and current studies, temperature between BEC zones and moisture within each BEC zone seems to have the largest effect on lodgepole pine growth, while moisture seems to have the largest effect on western gall rust and needle cast within the ICH and SBS zones.

Perhaps the knowledge most pertinent to managerial decisions is: which sites are most suitable for establishment of plantation lodgepole pine in interior BC. Overall, low to mid-elevation sites in the moist, mild ICH subzones and the dry, cool MS subzone along the Rocky Mt. Trench are the most desirable - high productivity and relatively low pest hazard. Though repeated needle cast can pose a threat to lodgepole pine plantations at these sites, highly resistant seed sources can effectively alleviate the problem $[12,24]$. At the most productive sites, e.g. Goat R., Sue Mile 25 (Fig. 1 and Tab. I), plantations with selected productive provenances coupled with intensive silviculture can probably be harvested on a 40- to 45-year rotation, and many of the fast growing provenances happen to be local [43, 45].

Productive lodgepole pine sites also exist across the vast stretch of the Interior extending from sites in the cold ICH subzone and the moist SBS subzones saddled at Skeena/Bulkley river basin extending west to Mackenzie, sites in moist, mild ICH subzones along the interior wetbelt on Shuswap-Quesnel Highland, to windward sites in dry, mild MS subzone on Thompson Plateau. The least productive sites are mostly along the western edge of the Interior, e.g. the very dry, cold SBPS in Chilcotin and in BWBS and SWB in the north where natural regeneration should stay the norm of managing lodgepole pine.

Sixty sites are a large number in a study of this nature, but still far from adequate to sample the complex environment of forest lands in the interior of British Columbia. However, regression models indicate a good predictability of at least the effect of coarse-grained environment on site productivity. As methodology on quantification of site edaphic factors, (e.g. nutrition and finer moisture regime) across BEC zones becomes available (D.V. Meidinger, personal communication), improved models derived from these test sites may be able to predict, with high precision, productivity as well as pest hazard. 


\section{REFERENCES}

[1] Bentz B.J., Amman G.D., Logan J.A., A critical assessment of risk classification system for the mountain pine beetle, For. Ecol. Manage. 61 (1993) 349-366.

[2] Brown J.K., Fire cycles and community dynamics in lodgepole pine forests, in: Baumgartner D.M. (Ed.), Management of lodgepole pine ecosystem, Cooperative Extension Service, Washington State University, Pullman, WA, 1973, pp. 429-456.

[3] Corns I.G.W., Pluth D.J., Vegetational indicators as independent variables in forest growth prediction in west-central Alberta, Canada. For. Ecol. Manage. 9 (1984) 13-25.

[4] Critchfield W.B., Genetics of lodgepole pine, USDA For. Serv. Res. Pap., 1980, W-37.

[5] Green R.N., Marshall P.L., Klinka K., Estimating site index of Douglas-fir (Pseudotsuga menziesii (Mirb.) Franco) from ecological variables in southwestern British Columbia, For. Sci. 35 (1989) $50-63$.

[6] Green R.N., Thrower J.S., Field guide insert for the estimation of coastal Douglas-fir site index from BEC site series, BC Min. For., 1993.

[7] Hiratsuka Y., Powell J.M., Pine stem rusts of Canada, Dept. Env., Can. For. Serv., For. Tech. Rep. No. 4, 1976.

[8] Hiratsuka Y., Powell J.M., van Sickle G.A., Impact of pine stem rusts of hard pines in Alberta and the Northwest Territories, Can For. Serv. North. For. Cent. Edmonton, AB. Inf. Rep. NOR-X-299, 1988, p. 9.

[9] Hoff R.J., Minggao S., Genetic variation in susceptibility of lodgepole pine to western gall rust in the Inland Northwest, USDA For. Serv. Res. Note INT-420, 1994.

[10] Holls C.A., Schmidt R.A., Site factors related to fusiform rust incidence in north Florida slash pine plantations, For. Sci. 23 (1977) 69-77.

[11] Hunt R.S., Pine needle cast and blights in the Pacific Region, Can. For. Serv. Pac. For. Res. Cent., For. Pest Leaf. No. 43, 1981.

[12] Hunt R.S., Ying C.C., Ashbee D., Variation in damage among Pinus contorta provenances caused by the needle cast fungus Lophodermella concolor, Can. J. For. Res. 17 (1987) 594-597.

[13] Illingworth K., General proposal for tree improvement with lodgepole pine - a problem analysis, BC Min. For., Res. Br. Unpubl. Rep., 1966, 18 p.

[14] Illingworth K., Considerations for a discussion on objectives, scope and design of the all-range lodgepole pine provenance trials, BC Min. For., Res. Br. Unpubl. Rep., 1969, 24 p.

[15] Klinka K., Carter R.E., Relationship between site index and synoptic environmental factors in immature coastal Douglas-fir, For. Sci. 36 (1990) 815-830.

[16] Krajina V.J., Biogeoclimatic zones and biogeocoenoses of British Columbia, Ecol. West. N. Amer. 1 (1965) 1-17.

[17] Lotan J.E., Brown J.K., Neuenschwander L.F., Role of fire in lodgepole pine forests, in: Baumgartner D.M. et al. (Eds.), Lodgepole pine: the species and its management, Cooperative Extension Service, Washington State University, Pullman, WA, 1985, pp. 133152.

[18] MacKinnon A., Meidinger D.V., Klinka K., Use of the biogeoclimatic ecosystem classification system in British Columbia, For. Chron. 68 (1992) 100-120.

[19] McLauchlan L.E., Borden J.H., Spatial attack dynamics and impact of Pissodes terminalis in three biogeoclimatic zones in southern BC, Min. For. Victoria, BC, 1994.

[20] McLennan D.S., Summary of site index statistics for lodgepole pine and interior spruce in ecosystems of the sub-boreal spruce and subboreal pine-spruce biogeoclimatic zones, BC Min. For. Contract Rep. 12095, 1989.
[21] Meidinger D., Pojar J., Ecosystems of British Columbia, BC Min. For., Res. Br. Victoria, BC, 1991, 330 p.

[22] Monserud R.A., Variation on a theme of site index, in: Ek A.R., Shifley S.R., Burk T.E. (Eds.), Forest growth modeling and prediction, US Dept. Agric. For. Serv. St. Paul, Minn. Gen. Tech. Rep. NC-120, 1987, pp. 419-427.

[23] Monserud R.A. Rehfeldt G.E., Genetic and environmental components of variation of site index in inland Douglas-fir, For. Sci. 36 (1990) $1-9$

[24] Pfister R.D., Daubenmire R., Ecology of lodgepole pine (Pinus contorta Dougl.), in: Baumgartner D.M. (Ed.), Management of lodgepole pine ecosystem, Cooperative Extension Service, Washington State University, Pullman, WA, 1973, pp. 27-46.

[25] Pojar J., Ecological classification of lodgepole pine in Canada, in Baumgartner D.M., et al. (Eds.), Lodgepole pine: the species and its management, Coop. Ext. Serv., Wash. Stat. Univ., Pullman, 1985, pp. $77-88$.

[26] Pojar J., Klinka K., Meidinger D.V., Biogeoclimatic Ecosystem Classification in British Columbia, For. Ecol. Manage. 22 (1987) $119-154$.

[27] Powell J.P., Hiratsuka Y., Serious damage caused by stalactiform blister rust and western gall rust to a lodgepole pine plantation in central Alberta, Can. Plant Dis. Surv. 53 (1973) 67-71.

[28] SAS Institute Inc., SAS ${ }^{\circledR}$ STATS Guide, $1 \& 2$, Version 6, 2nd ed., Cary, NC. USA, 1990.

[29] Sieben B.G., Climatically based hazard rating system for spruce weevil, Pissodes strobi, in the Prince George Forest Region under present and climate change conditions, M.Sc. thesis, Fac. of For. Univ. BC, Vancouver, BC, 1994.

[30] Stanek W., Relative quality of the major forest associations of the southern BC interior for growth of lodgepole pine, Engelmann spruce, Douglas-fir and alpine fir, For. Chron. 42 (1966) 306-313.

[31] Steel R.G.D., Torrie J.H., Principles and procedures of statistics, a biometrical approach, 2nd ed., McGraw-Hill, New York, 1980.

[32] Stevens R.E., Knopf J.A.E., Lodgepole terminal weevil in interior lodgepole forests, Environ. Entomol. 3 (1974) 998-1002.

[33] Van der Kamp B.J., Lodgepole pine stem diseases and management of stand density in the British Columbia interior, For. Chron. 70 (1994) 773-779.

[34] Wang Q., Ecological and height growth analysis of some subboreal immature lodgepole pine stands in central British Columbia, Ph.D. thesis, Fac. For. Univ. BC, Vancouver, BC, 1992, 207 p.

[35] Wang Q., Wang G.G., Coates K.D., Klinka K., Use of site factors to predict lodgepole pine and interior spruce site index in the subboreal spruce zone, Res. Note No. 114, Min. For. Victoria, BC, 1994.

[36] Weisberg S., Applied Linear Regression, 2nd ed., John Wiley and Sons, NY, 1985.

[37] Wood C.S., Van Sickle G.A., Shore T.L., Forest insect and disease conditions in British Columbia and the Yukon Territory, Can. For. Serv. Pac. For. Res. Cent. Rep. BC-X-259, 1984.

[38] Wood C.S., Van Sickle G.A., Shore T.L., Forest insect and disease conditions in British Columbia and the Yukon Territory, Can. For. Serv. Pac. For. Res. Cent. Rep. BC-X-345, 1993.

[39] Wu H.X., Muir J.A., Ying C.C., Effect of geographic variation and jack pine introgression on disease and insect resistance in lodgepole pine, Can. J. For. Res. 26 (1996) 711-726.

[40] Wu H.X, Ying C.C., Genetic parameters and selection efficiencies in resistance to western gall rust, stalactiform blister rust, needle cast and Sequoia pitch moth in lodgepole pine, For. Sci. 43 (1997) $571-581$.

[41] Wu H.X., Ying C.C., Variation in reaction norm of natural lodgepole pine populations, Theor. Appl. Genet. 103 (2001) 331345. 
[42] Xie C.-Y., Ying C.C., Genetic architecture and adaptive landscape of interior lodgepole pine (Pinus contorta ssp. latifolia), Can. J. For. Res. 25 (1995) 2010-2021.

[43] Xie C.-Y., Ying C.C., Heritability, age-age correlation and early selection in lodgepole pine (Pinus contorta ssp. latifolia), Silvae Genet. 45 (1996) 101-107.

[44] Yanchuk A.D., Yeh F.C., Dancik B.P., Variation of stem rust resistance in a lodgepole pine provenance-family plantation, For. Sci. 34 (1988) 1067-1075.

[45] Ying C.C., Illingworth K., Carlson M., Geographic variation in lodgepole pine and its implication for tree improvement in British
Columbia, in: Baumgartner D.M. et al. (Eds.), Lodgepole pine: the species and its management, Coop. Ext. Serv., Wash. Stat. Univ., Pullman, 1985, pp. 45-53.

[46] Ying C.C., Illingworth K., Lodgepole pine provenance research in northwestern Canada with particular reference to the Yukon Territory, Dept. For. Gen. Plant Physiol. Swed. Univ. Agric. Sci. Umea, Rep. 6 (1986) 189-219.

[47] Ying C.C., Hunt R.S., Stability of resistance among Pinus contorta provenances, Can. J. For. Res. 17 (1987) 1596-1601.

[48] Ziller W.G., The tree rusts of western Canada, Can. For. Serv. Pac For. Res. Cent. Publ. No. 1329, 1974.

To access this journal online: www.edpsciences.org 